\title{
Factors influencing the growth of intensively reared kids from birth to twelve weeks of age
}

\author{
H. HARRICHARAN, H. RAMLAL ${ }^{(*)}$, B. LAUCKNER \\ Carribean Agricultural Research and Development Institute, University Campus, \\ St. Augustine, Trinidad, West Indies
}

\begin{abstract}
Summary
Production data from four breeds of goats (Anglo-Nubian, Saanen, Toggenberg and Alpine), were collected over a five year period to determine the influence of breed, type of birth, sex and year of birth on birth weight, 12-week weaning weight and average daily gain from birth to 12 weeks of age.

All factors investigated influenced significantly $(P<0.05)$ the birth weight. Type of birth was the only factor which did not have a significant influence on the 12 -week weight. There were no interactions influencing the birth weight of kids. However, the 12-week weight and average daily gain were influenced by year of birth $\times$ sex and year of birth $\times$ breed interactions. Loss of kids between years was significantly $(\mathrm{P}<0.001)$ different but there was no difference due to breed, sex and type of birth. The average loss per year was $34 \%$. Losses ranged from 8 to $53 \%$.

The phenotypic correlations between birth weight and 12 -week weight and average daily gain from birth to 12 weeks of age were 0.32 and 0.06 , respectively. The phenotypic correlation between 12-week weight and average daily gain was 0.96 . Under the system of management, the results suggest that the 12 -week weight would provide a good guide for the selection of herd replacements.
\end{abstract}

Key words : Goat, kid weight factors, breed, sex.

\section{Introduction}

There is increasing interest in the production of meat from small ruminants in the Caribbean. In order to increase production, efforts must be directed at improvement in the feeding, breeding and management of these animals.

To improve breeding, attempts must be made to select superior breeding stock to be parents of successive generations so as to make an impact on the animal population in the region. Selection can only be effective when animals are compared on an equal basis to identify those that are superior.

The growth of animals is influenced by both genetic and environmental factors and if these are incorrectly evaluated errors could arise in selecting the superior individuals.

$\left({ }^{*}\right)$ Ministry of Agriculture, Lands and Food Production, Centeno Via Post Office Arima, Trinidad, West Indies. 
It is therefore essential to obtain a knowledge of the factors influencing growth and the present study was undertaken to evaluate the influence of factors such as breed, type of birth (singles, twins or triplets), sex and year of birth on the birth weight, 12-week weaning weight and weight gain from birth to 12 weeks of age on four imported breeds of goats found in different parts of the Caribbean.

\section{Materials and methods}

Anglo-Nubian, Alpine, Saanen and Toggenburg goats were imported into Trinidad \& Tobago periodically and reared on the Government Stock Farm at St. Joseph with a view to multiplying these breeds to sell improved breeding stock to farmers and to upgrade the indigenous breeds of goats in the country. Indigenous breeds are excluded from the farm and data on these breeds were not available for comparison with the imported breeds. Kids of the imported breeds are selected at an early age as herd replacements and the remainder are sold as breeding stock to farmers. The poor animals are culled. Because emphasis is placed on meat production one criterion used in the selection programme is the average daily gain from birth to 12 weeks of age or the 12-week weight.

The goats on the Farm were reared indoors under an intensive system. The kids were separated from their dams within the first 24 hours after birth and reared in pens with no more than 3 kids per pen. They are fed with their dam's colostrum in the first few days, and thereafter they were fed with fresh bulked whole goats' milk. From the third week after birth a commercial dairy concentrate (containing cp $160 \mathrm{~g}$ per $\mathrm{kg}$; digestible energy 12.4 megajoules per $\mathrm{kg}$, as fed basis) and fresh-cut forage were offered to the kids. All kids were placed on the same feeding regime receiving $227 \mathrm{~g}$ of the whole goat's milk three times daily up to the sixth week, thereafter the amount was increased to $454 \mathrm{~g}$ and fed twice a day up to the 10th week of age. Between the 11th and 12th week of age, whole milk was reduced to $227 \mathrm{~g}$ and fed only once a day. Concentrates were offered once per day at the rate of $227 \mathrm{~g}$ between the 7 th and 10 th week and this was increased to $454 \mathrm{~g}$ per day from the 11th week. Mixed forage species were offered ad libitum.

The young kids were de-horned within 10 days of birth. An antihelminthic was given at 8 weeks of age and thereafter the frequency of deworming was based on faecal egg counts.

Birth weight of the animals were recorded within 24 hours of birth, the litter sequence and age of dam were, however, not available. The kids were also weighed at 12 weeks of age. The average daily gain (ADG) was obtained by subtracting the individual birth weight from the 12-week individual weight of the surviving kids and dividing the weight gain by 84 days. Deaths were recorded but their causes were not entered in the records on the station. The correlation coefficients were computed from the data on the kids surviving at 12-weeks of age.

The data used in this study were abstracted from records for the period 1978-1982. Linear models of the type :

$$
\mathrm{Y}=\sum_{\mathrm{x}=1}^{\mathrm{m}} \boldsymbol{\beta}_{\mathrm{i}} \mathbf{x}_{\mathrm{i}}
$$


were fitted as described by NELDER \& WEDDERBurn (1972). The $\mathrm{x}_{\mathrm{i}}$ independent variates were qualitative and represented the four animal breeds, three types of birth (singles, twins or triplets), two sexes, five years of records and also all interaction terms associated with these factors. The independent variables were assumed to have a normal error structure. The parameters $\beta_{i}$ were estimated from the data using the GLIM system (NELDER, 1974). An analysis of deviance was built up from the computed output and the results outlined below. None of the second and third order interactions were significant and thus they are not discussed.

\section{Results and discussion}

The number of observations, mean birth weights, 12-week and daily weight gain from birth to 12-week of age are shown in Table 1. The sub-class means for year $\times$ breed and year $\times$ sex interactions for 12 -week weight and average daily gains are shown in Table 2 .

TABLE 1

Mean birth weight, 12-week weight, average daily gain and percent loss of four breeds of kids born and reared at the Government Stock Farm in Trinidad between 1978 and 1982.

\begin{tabular}{|c|c|c|c|c|c|c|c|c|c|c|}
\hline \multirow[t]{2}{*}{ Classification } & \multicolumn{3}{|c|}{$\begin{array}{c}\text { Birth weight } \\
(\mathrm{kg})\end{array}$} & \multicolumn{3}{|c|}{$\begin{array}{c}\text { 12-week weight } \\
(\mathrm{kg})\end{array}$} & \multicolumn{3}{|c|}{$\begin{array}{l}\text { Average daily gain } \\
\text { (g) }\end{array}$} & \multirow{2}{*}{$\begin{array}{c}\text { Loss (Birth } \\
\text { 12-weeks) }\end{array}$} \\
\hline & No. & Mean & S.E. & No. & Mean & S.E. & No. & Mean & S.E. & \\
\hline $\begin{array}{c}\text { All Kids } \ldots . \\
\text { Breed }\end{array}$ & 280 & 3.21 & 0.04 & 184 & 11.3 & 0.2 & 184 & 96 & 2 & 34 \\
\hline Anglo Nubian & 150 & 3.25 & 0.05 & 94 & 10.7 & 0.2 & 94 & 91 & 2 & 37 \\
\hline Saanen ..... & 65 & 2.88 & 0.07 & 50 & 11.5 & 0.3 & 50 & 102 & 3 & 23 \\
\hline Toggenburg . & 45 & 3.36 & 0.09 & 30 & 11.8 & 0.4 & 30 & 102 & 4 & 33 \\
\hline Alpine .... & 20 & 3.68 & 0.13 & 10 & 13.8 & 0.7 & 10 & 119 & 7 & 50 \\
\hline $\begin{array}{l}\text { Significance } \\
\text { (See below) }\end{array}$ & & $* * *$ & & & $* *$ & & & $* *$ & & N.S. \\
\hline \multicolumn{11}{|l|}{ Type of birth } \\
\hline Singles . . . . & 80 & 3.51 & 0.08 & 49 & 11.6 & 0.3 & 49 & 98 & 3 & 39 \\
\hline Twins $\ldots \ldots$ & 158 & 3.14 & 0.05 & 103 & 11.3 & 0.2 & 103 & 97 & 2 & 35 \\
\hline Triplets .... & 42 & 2.90 & 0.09 & 32 & 10.9 & 0.4 & 32 & 94 & 4 & 24 \\
\hline Significance. . & & $* * *$ & & & N.S. & & & N.S. & & N.S. \\
\hline \multicolumn{11}{|l|}{ Sex } \\
\hline Male . . . . . & 130 & 3.37 & 0.05 & 90 & 12.9 & 0.2 & 90 & 107 & 2 & 31 \\
\hline Female . . . . & 150 & 3.07 & 0.05 & 94 & 10.2 & 0.2 & 94 & 87 & 2 & 37 \\
\hline Significance . . & & $* * *$ & & & $* * *$ & & & $* * *$ & & N.S. \\
\hline \multicolumn{11}{|l|}{ Year of birth } \\
\hline $1978 \ldots$ & 58 & 2.90 & 0.08 & 27 & 10.6 & 0.4 & 27 & 92 & 5 & 53 \\
\hline 1979 & 55 & 3.18 & 0.08 & 36 & 10.5 & 0.4 & 36 & 86 & 4 & 35 \\
\hline $1980 \ldots \ldots$ & 45 & 3.31 & 0.09 & 29 & 10.6 & 0.4 & 29 & 87 & 4 & 36 \\
\hline $1981 \ldots \ldots$ & 37 & 3.28 & 0.09 & 43 & 13.1 & 0.3 & 43 & 118 & 4 & 9 \\
\hline $1982 \ldots \ldots$ & 75 & 3.30 & 0.09 & 49 & 11.2 & 0.3 & 49 & 94 & 3 & 35 \\
\hline Significance . . & & $* *$ & & & $* * *$ & & & $* * *$ & & $* * *$ \\
\hline
\end{tabular}

N.S. $\mathrm{p}>0.05:{ }^{*} \mathrm{p}<0.05 ;{ }^{* *} \mathrm{p}<0.01 ;{ }^{* * *} \mathrm{p}<0.001$. 


\section{A. Factors influencing birth weight}

The mean birth weight of 280 kids born in the herd over the five year period (1978-1982) was $3.21 \pm 0.04 \mathrm{~kg}$ (Table 1). Mean birth weight of kids from exotic breeds and their crosses in the tropics have been reported (Devendra \& Burns, 1970) to range from 1.4 to $4.0 \mathrm{~kg}$. Thus, the mean birth weight of $3.21 \mathrm{~kg}$ obtained in the present study for the purebred kids falls within the range of birth weight of similar breeds elsewhere in the tropics.

\section{B. Breed}

The observed difference in the birth weight of the heaviest and lightest breeds was $0.80 \mathrm{~kg}$. The mean birth weight of the Alpine kids was $3.68 \mathrm{~kg}$ and was the heaviest among the breeds studied. Although, they were not significantly heavier than Toggenburg, they were significantly heavier than Anglo-Nubian $(P<0.05)$ and Saanen $(P<0.001)$ kids. Saanen kids had the lowest birth weight $(2.88 \mathrm{~kg})$. The birth weights obtained in the present study are similar to those reported for the same breeds by KeEPing (1951) \& DeVEndRa (1962).

Variation in birth weight between breeds is due mainly to genetic factors. Hence, where replacements are selected on birth weight, the progeny of those breeds are known to have heavier birth weight, as may have been the case for the Alpines in this study.

\section{Type of birth}

Single kids were significantly $(P<0.001)$ heavier than twins and triplets and twins heavier than triplets (Table 1). The mean difference in the birth weight of kids born as singles and triplets was $0.61 \mathrm{~kg}$. Whereas the differences in the present study are large and significant, EPSTEIN \& HERTz (1964) found only small non-significant differences in birth weight of singles and twins of exotic and indigenous breeds of goats in Israel. However, Sacker \& Trail. (1966) and WiJeratne (1968) found significant differences in the birth weight of kids born as singles, twin and triplets in indigenous breeds of goats in East Africa and South India, respectively.

\section{Sex}

Male kids were significantly $(P<0.001)$ heavier at birth than females, with a mean difference of $0.30 \mathrm{~kg}$ (Table 1). Similarly sex differences in the birth weight of kids from exotic breeds in the tropics have been reported elsewhere [KEEPING (1951); Devendra (1962)]. Ali (1980) observed the same trend with Black Bengal kids and Sacker \& Trail (1966) found a similar trend in the Mubande kids in East Africa.

\section{E. Year of birth}

Differences in year of birth on birth weight (Table 1) were significant $(\mathrm{P}<0.05)$. The maximum differences in the birth weight of the kids born between the best year (1980) and the worst year (1978) was $0.41 \mathrm{~kg}$. The birth weight of the kids born in 1978 
was significantly lower than all other years. The differences in the birth weight of kids born in the years after 1978 may be due to changes in the management which occurred after that year. Differences in the birth weight of kids due to year of birth were observed and reported by SACKER \& Trail (1966).

\section{F. Interactions}

The first order interactions among the factors influencing birth weight were not significant.

\section{G. Factors influencing 12-week weight and $A D G$}

The results in Table 1 show that breed, sex and year of birth each had a significant $(P<0.001)$ influence on the 12-week weight of the kids. The influence of type of birth had no significant effect on 12-week weight. Year of birth $\mathrm{x}$ breed and year of birth $\mathrm{x}$ sex interactions had significant $(P<0.05)$ influences on 12 -week weight (Table 2).

The average 12-week weight of the kids was $11.3 \pm 0.2 \mathrm{~kg}$ and the average daily gain from birth to 12-weeks was $96 \pm 2 \mathrm{~g}$. The mean 12-week weight and ADG of the kids in this study are similar to the values obtained by WILSON et al. (1980) for AngloNubian and Anglo-Nubian crossbred kids weaned at 90 days of age.

\section{H. Breed}

Breed had a significant influence on the 12-week weight and average daily gain of the kids (Table 1). The mean 12-week weight of Anglo-Nubian, Saanen, Toggenburg and Alpine kids were $10.7,11.5,11.8$ and $13.8 \mathrm{~kg}$, respectively, and the corresponding average daily gains were 91, 102, 102 and $119 \mathrm{~g}$. The Alpine kids were heavier at birth and continued to be heavier at weaning. The average daily gain made by the kids in the present study were lower than the gains of 209 to $241 \mathrm{~g}$ made by Alpine kids between 57 and 81 days old, raised artificially on a high plane of nutrition (FEHR et al., 1976). The average daily gain (104 g) made by Anglo-Nubian and Anglo-Nubian crossbred kids reported by WILson et al. (1980) were higher than the gain made by the purebred Anglo-Nubian in the present study.

\section{Type of birth}

Type of birth (litter size) had no significant influence on the 12-week weight nor on the average daily gain of the kids (Table 1). The mean average daily gain of singles, twins and triplets were 98,97 and $94 \mathrm{~g}$, respectively. Since the kids were all reared artificially any disadvantages arising from the lower birth weight of twins and triplets or the dam's milk production were not noticeable at 12-weeks. WiJeratNe (1968) found differences in the weaning weight of singles, twins and triplets from indigenous local breeds of South Indian goats suckling their dams. In that study single kids were heavier than twins and twins were heavier than triplets at six months of age and this trend continued to the yearling stage. 


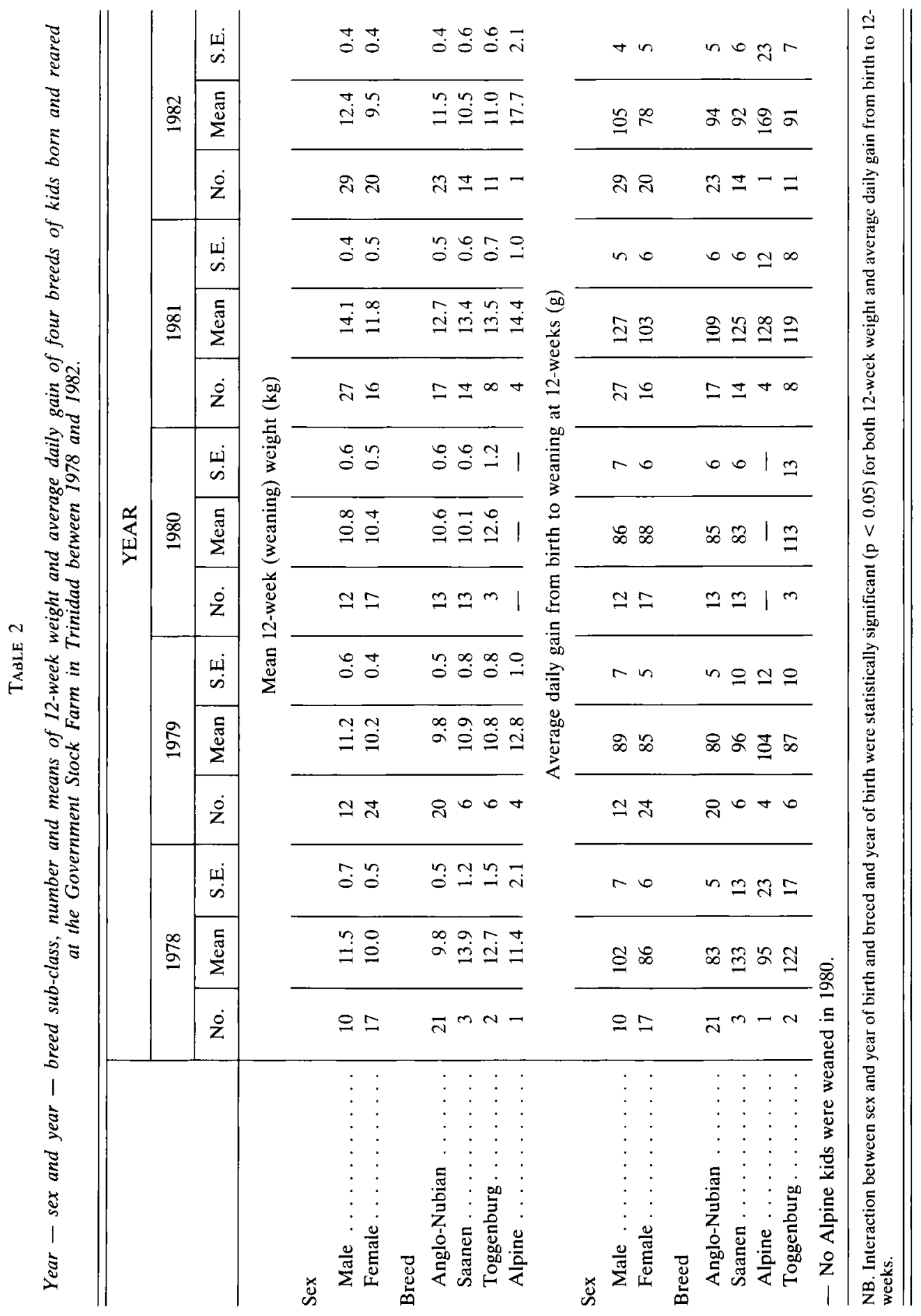




\section{J. Sex}

Male kids were significantly $(P<0.001)$ heavier than females at 12 -weeks of age (Table 1). Males weighed $12.9 \mathrm{~kg}$ and females $10.2 \mathrm{~kg}$. This was reflected in the daily gain of $107 \mathrm{~g}$ made by males, compared with $87 \mathrm{~g}$ by the females. Sex difference in the 12-week weight of kids was observed by DEVENDRA (1966) and a higher rate of daily gain in small East African male kids was reported by WiLson (1958). Ali (1980) found the reverse trend in Black Bengal goats in that the females grew faster than the males from about the eighth week of age.

\section{K. Year of birth}

The year in which the kids were born had a highly significant $(P<0.001)$ influence on their 12-week weight and average daily gain (Table 1). The influence of year on growth of the kids may have been the result of changes in management, incidence of diseases and other environmental factors. The kids 12-week weight increased in 1981 but declined again in 1982 when the herd was plagued by health problems.

\section{Interactions}

The year of birth $\mathrm{x}$ sex and year of birth $\mathrm{x}$ breed interactions were statistically significant $(P<0.05)$ for the 12 -week weight and average daily gain of the kids. The data in Table 2 show that differences in 12-week weight between males and females were variable from year to year and suggest that breed and sex differences were not consistent in different years. For example in 1982 while the difference in the average weaning weight between males and females was $2.9 \mathrm{~kg}$, in 1980 the differences was only $0.4 \mathrm{~kg}$. Similarly, males made higher average daily gain during 1981 and 1982 of 24 and $27 \mathrm{~g}$, respectively. But, in 1979 and 1980 there were no significant differences in average daily gain between the sexes.

There were also significant $(P<0.05)$ interactions between breed and year of birth for 12-week weight and average daily gain of the kids. However it should be noted that the number of observations per year in some breeds was small and hence the results need to be interpreted with caution.

\section{Kid mortality}

The mortality of kids from birth to 12 -weeks of age can be ascertained from Table 1 by comparing the number of observations at birth with those at 12-weeks. Over the five year period $34 \%$ of the kids died before they were 12-weeks old. The losses varied from year to year and they were highest in the first year (1978) but reduced to an acceptable level in 1981. The reduction in 1981 may be attributed to improved management practices introduced in the herd.

Chi Square tests on the data for losses revealed that while losses between year were significant $(P<0.001)$, losses between breed, sex and type of birth were not statistically significant.

Studies reported by Ahmed \& Tantawy (1960), Sacker \& Trail (1966) and MineTT (1950) recorded kid mortality rates ranging from 24 to $55 \%$ per annum. 
Sacker \& Trail (1966) observed highest losses in litters with twins and triplets and found that $55 \%$ of the triplets raised out-doors with their dams died before they were 3 weeks old. They also observed that the losses can be significantly reduced when the kids are housed continuously in the first 3 weeks after birth.

In the present study the loss of singles, twins and triplets were 39,35 and $24 \%$, respectively. The lower losses observed here among twins and triplets can be attributed to the fact that the kids were reared in a controlled environment and fed individually.

\section{N. Correlations}

The correlations (Table 3) between birth weight and 12-week weight, birth weight and average daily gain and 12 -week weight and average daily gain were $0.32,0.06$ and 0.96 , respectively. The phenotypic correlation between birth weight and average daily gain was almost zero indicating that if selection were to be made on the phenotypic correlation of birth weight and average daily gain the rate of genetic improvement for those traits would be very slow.

TABLE 3

Phenotypic correlations ( $r$ ) between birth weight, 12-week weight and average daily gain of four breeds of kids born and reared at the Government Stock Farm in Trinidad between 1978 and 1982.

\begin{tabular}{l|l|c|c}
\hline \hline \multicolumn{1}{c|}{ Traits } & Birth weight & 12-week weight & $\begin{array}{c}\text { Average daily } \\
\text { gain }\end{array}$ \\
\hline Birth weight $\ldots \ldots \ldots \ldots \ldots \ldots \ldots \ldots \ldots \ldots$ & 1.00 & - & - \\
12-week weight $\ldots \ldots \ldots \ldots \ldots \ldots \ldots \ldots \ldots$ & $0.32^{* * *}$ & 1.00 & - \\
Average daily gain $\ldots \ldots \ldots \ldots \ldots \ldots \ldots$ & 0.06 & $0.96^{* * *}$ & 1.00 \\
\hline${ }^{* * *} \mathrm{p}<0.001$.
\end{tabular}

The phenotypic correlation between 12-week weight and average daily gain in the present study $(\mathrm{r}=0.96)$ was high. SACKer \& TRAIL $(1966)$ in their study on Mubende goats found low ( $\mathrm{r}=0.02$ to 0.16 ) phenotypic correlations between birth weight and weights at different ages. In the same study it was observed that weaning and yearling weight were highly correlated $(r=0.48)$. WiJERATne $(1968)$ found that the phenotypic correlation in indigenous breeds of South Indian goats between birth and yearling weight was high and that between 6-month and yearling weight was even higher $(r=0.82)$. It was concluded in that study that birth weight can be used as a good guide to select replacements to increase the weaning and yearling weight of those breeds. AlI (1980) observed that the phenotypic correlation between birth weight and weights of the $1 \mathrm{st}, 4 \mathrm{th}, 8$ th and 13 th weeks of age declined rapidly with increase in age in both males and females.

The results obtained in this study suggest that selection to increase the 12-week weight in the herd should be based on the body weight of the kids at 12-weeks of age.

Reçu en décembre 1986. 


\section{Résumé \\ Facteurs influençant la production de chevreaux élevés intensivement de la mise bas jusqu'à l'âge de douze semaines}

Des données ont été rassemblées sur une période de 5 ans pour déterminer l'influence de la race, de la taille de portée, du sexe et de l'année de naissance sur le poids de naissance, le poids vif à 12 semaines et le gain moyen quotidien chez des chevreaux de 4 races différentes (AngloNubien, Saanen, Toggenburg et Alpine).

Tous les facteurs influencent de façon significative le poids de naissance $(p<0,05)$, sans interaction entre eux. La taille de la portée est le seul facteur qui n'a pas d'effet sur le poids à 12 semaines, ou sur le gain moyen quotidien qui sont tous les deux influencés par les interactions année de naissance $x$ sexe et année de naissance $x$ race.

Les pertes en chevreaux d'une année à l'autre montrent une différence significative $(p<0,01)$ mais, il n'y a pas de différences dues à la race, le sexe ou la taille de portée. La perte moyenne par année est de $34 \%$, les pertes étant comprises entre 8 et $53 \%$.

Les corrélations entre le poids de naissance et le poids à 12 semaines d'une part et le poids de naissance et le gain moyen quotidien d'autre part sont respectivement de 0,32 et 0,06 . La corrélation entre le poids à 12 semaines et le gain moyen quotidien est de 0,96. Dans nos conditions d'élevage, ces résultats suggèrent que le poids à 12 semaines est un bon prédicteur pour sélectionner les animaux en vue du renouvellement du cheptel.

Mots clés: Chèvre, chevreau, facteurs de croissance, élevage, sexe.

\section{References}

Ahmed I.A., Tantawy A.O., 1960. Studies on Egyptian Baladi goats. II Some factors affecting mortality rates. Emp. J. Exp. Agric., 28, 104-108.

AlI S.Z., 1980. Relation to birth weight of kids to their post-natal growth in Black Bengal goats. Ind. Vet. J., 57, 1006-1008.

Devendra C., 1962. Upgrading of local goats by the Anglo-Nubian at the Federal Experiment Station, Serdang, Malay. Agric. J., 43, 265-280.

Devendra $C_{\text {. }}, 1966$. Studies in the nutrition of indigenous goats of Malay 1. The body measurements, composition of sample joints and their relationship to carcass composition. Malay. Agric. J., 45, 345-369.

Devendra C., Burns M., 1970. Goat production in the tropics. Commonwealth Agricultural Bureaux, Farnham Royal, England, 413 p.

Epstein H., Herz A., 1964. Fertility and birth weights of goat in a sub-tropical environment. $J$. Agric. Sci. Camb., 62, 237-244.

Fehr P.M., Sauvant D., Delage J., Dummont B.L., Roy G., 1976. Effect of feeding methods and carcass characteristics of entire young male goats. Livestock Prod. Sci., 3, 183-189.

KEEPING G.S., 1951. A review of progress recorded in the up-grading and breeding of pedigree imported and local goats. Malay. Agric. J., 34, 32-39.

Minetr E.C., 1950. Mortality in sheep and goats in India. India J. Vet. Sci., 20, 69-103.

Nelder J.A., 1974. The GLIM Manual. Release 1. Oxford: Numerical Algorithms Group. Mimeo, $51 \mathrm{p}$.

Nelder J.A., Wedderburn R.W.M., 1972. Generalized Linear Models. J.R. Statis. Soc. B., 34, 370-384. 
Sacker G.D., Trail J.C.M., 1966. Production characteristics of a herd of East African Mubande goats. Trop. Agric. (Trinidad), 43, 43-51.

WIJERATNE W.V.S., 1968. The production traits of a non-descript breed of South Indian meat goats. Trop. Agric. (Trinidad), 45, 39-45.

WILSON P.N., 1958. The effect of plane of nutrition on the growth and development of the East African dwarf goat. Effect of plane of nutrition on the live-weight gains and external measurements of kids. J. Agric. Sci. Camb., 50, 198-210.

Wilson L.L., Katsigianiss T.S., Dorsett A.A., Cuthopoulis Greams A.G., Baylor J.E., 1980. Performance of native and Anglo-Nubian Crosses and observations on improved pasture of goats in the Bahamas. Trop. Agric. (Trinidad), 51, 183-190. 